\title{
PESAN KOMUNIKASI DALAM PENGGALANGAN DANA MELALUI WEBSITE
}

\author{
Drina Intyaswati \\ Prodi Ilmu Komunikasi FISIP UPN “Veteran” Jakarta \\ nanazain@gmail.com
}

\begin{abstract}
A website is widely used as a means of fundraising (fundraiser). The purpose of this study was to determine how the communication message conveyed in fundraising efforts through media website. By taking samples of the two types of websites as Fundraiser, wanted to also see each similarities and differences in communication strategies do. The analysis used is content analysis which analyzes the results of observations of the website Kitabisa.com and GandengTangan.org. Thus this type of research is qualitative descriptive. In conclusion there are similarities in general body of the message from both the website, there are differences in the nature of fundraising, and different from the long campaign period.
\end{abstract}

\begin{abstract}
Abstrak
Media website banyak digunakan sebagai sarana penggalangan dana (fundraiser). Tujuan dari penelitian ini adalah untuk mengetahui bagaimana pesan komunikasi yang disampaikan dalam usaha penggalangan dana melalui media website. Dengan mengambil sampel dua jenis website sebagai Fundraiser juga dilihat masing- masing persamaan dan perbedaan dari strategi komunikasi yang dilakukan. Analisis yang digunakan adalah analisis isi,yang menganalisishasil observasi dari website Kitabisa. com dan GandengTangan.org. Dengan demikian jenis penelitian ini adalah kualitatif deskriptif. Kesimpulannya secara umum terdapat persamaan isi pesan dari kedua website tersebut, perbedaannya terdapat pada sifat penggalangan dana, serta berbeda pada lama masa kampanye.
\end{abstract}

Keywords: Fundraising, Communication Messages, Website

\section{PENDAHULUAN}

\section{Latar Belakang}

Dalam dasa warsa terakhir di Indonesia muncul konsep-konsep tentang Usaha Sosial (social enterprise), Kewirausahaan Sosial (social entrepreneurship), dan Pemilik Usaha Sosial (social entrepreneur). Pada dasarnya mereka memiliki perilaku kewirausahaan dengan tujuan sosial dan berorientasi non profit.Empat kriteria yang mencerminkan dimensi ekonomi dan kewirausahaan sosial perusahaan adalah: kegiatan memproduksi secara terus menerus barang dan atau jasa,tingkat otonomi tinggi,adanya signifikansi risiko ekonomi, jumlah minimum pekerjaan yang dibayar(Jacques, 2010, 8). Definisi perusahaan sosial adalah segala jenis organisasi atau usaha yang bergerak di kegiatan yang bernilai sosial yang signifikanatau dalam produksi barang dan jasa yang memilki nilai tujuan sosial, terlepas dari bentuk hukumnya.

Sehubungan dengan sifat otonominya 
yang tinggi, banyak dari perusahaan sosial tersebut yang mengusahakan dananya dari masyarakat. Penggalangan dana sosial ini dikenal dengan istilah fundraising. Munculnya gerakan penggalangan dana lokal ini di-picu oleh munculnya berbagai bencana alam yang melandaIndonesia; tanah longsor, gempa bumi, kebakaran, gelombang tsunami, dan bencana-bencana lain yang mengakibatkan banyak korban secara berkelanjutandi negara ini. Munculnya kreatifitas ini dimotivasi oleh kesadaran bahwanegara donor tidak selamanya akan membantu Indonesia, sehingga perlukiranya alternatif dan diversifikasi sumber penggalangan dana untukmengantisipasi jika suatu saat negara donor meninggalkan Indonesia. Kegairahan dan kegeliatan ini bisa kita baca melalui maraknya publikasi solidaritas sosial,baik di media cetak maupun elektronik. Dalam dunia usaha, kegiatan corporate philanthropy (kedermawanan sosial) sudah berlangsung semakin semarak.

Fundraising adalah proses mempengaruhi masyarakat baikperorangan atau lembaga agar menyalurkan dana, sumber daya non-dana, simpati atau dukungan kepada komunitas. Inti fundraising adalah menawarkan program unggulan atau kualitas kinerja lembaga/komunitas kepada masyarakat (donatur), sehingga masyarakat dapat mendukung dan berpartisipasi. Jadi mencermati pengertian ini bahwa fundraising bukanlah membudayakan meminta-minta kepada orang lain, namun menawarkan program kerja kepada mitra (Muhsin, 2004, $113)$.

Fundraiser harus mampu memahami sudut pandang donatur, karena menggalang danaselalu berhubungan dengan orang sebagaimana menjual barang. Fundraising bukan saja mengenai meminta, tetapi lebih banyak mengenai menjual.Tekniknya tentu harus meyakinkan orang agar mau menyumbang dan menunjukkan alasan mengapa kegiatan bersangkutan menjadi penting. Salah satu teknik penggalangan dana adalah Campaign. Kampanye atau Campaign adalah strategi penggalangan dana dengan cara melakukankampanye lewat berbagai media komunikasi.

Media yang digunakan dapat berupa poster, brosur, spanduk, liflet, stiker, media cetak dan elektronika,internet, dan sebagainya. Fungsi media campaign iniadalah sebagaikomunikasi dan promosi program lembaga, merawat donatur danmendapatkan penghasilan yang memadai. Bentuk dari model ini adalahbisa berbentuk iklan, laporan keuangan, liputan program, profil donaturdan profil penerima bantuan.

Bedasar fenomena yang terjadi diatas, dilakukan penelitian untuk melihat bagaimana konsep tentang kewirausahaan sosial di Indonesia, sebelumnya Jacques Defourny (2010) telah menulis bagaimana konsep kewirausahaan di Eropa dan Amerika.

Muhsin Kalida (2004) dalam tulisannya menyatakan bahwa untuk menghasilkan penggalangan dana yang efektif diperlukan kemampuan berkomunikasi dengan segala teknik-tekniknya. Hasil penelitian tersebut membuat penulis juga ingin melihat bagaimana praktek penggalangan dana dilakukan dengan strategi campaign melalui media internet atau website dan bagaimana pesan komunikasi yang disampaikan.

Pemilihan media internet atau website sebagai media dalam melakukan kampanye karena website termasuk dalam media baru. Yang membedakan media baru dari media konvensional adalah; Pertama, Packet Switcing. Packet switching adalah salah satu bagian yangmembedakan antara internet dengan media komunikasi yang lain, yaitu cara yang berbeda dalammenyampaikan sebuah pesan, data yang berupa teks, gambar maupunsuara dapat dikirimkan secara bersamaan, tanpa terkurangi sedikitpun. Kedua, Multimedia. Salah satu karakteristik mediainternet adalah multimedia. Pesan yang dikirimkan melalui media internet dapat dikemas dalam berbagai bentuk multimedia, baik suara, gambar maupun video. Kesemuanya dapat disajikan secara bersamaan dan melalui beberapa channel.

Ketiga, Interactivity. Bersifat interaktif, dimana komunikator dan komunikan 
bisa saling berhubungan secara real time sebagaimana apabila keduanya bertatap muka secara langsung. Dalam konteksmedia baru sebagai sumber informasi, pengguna dapat menjadi produser dan konsumer dalam waktu yang bersamaan, di saat pengguna mengkonsumsi sebuah berita, maka di saat yang sama pengguna dapat memproduksi sebuah berita baik di halaman yang sama maupun berbeda. Keempat, Synchronicity. Pertukaran pesan yang dilakukan melalui media internet tidak hanya memindahkan pesan begitu saja, tetapi dengan media internet, tidak adalagi batasan ruang dan waktu, semuanya dapat dilakukan kapan dan di mana saja.

Kelima, Hypertextuality. Media internet menyajikan sesuatu yang berbeda dengan media konvensional, baik segi mengkonsumsinya maupun cara memproduksinya. Dalam memproduksi sebuah pesan di media konvensional, diharuskan mengikuti aturan-aturan pada umumnya. Apabila pesan berupa text, maka cara penulisannya pun harus berurutan dan mengikuti aturan penulisan yang baku. Dan akan berbeda lagi jika pesan tersebut berupa sebuah halaman-halaman kertas, maka caramengkonsumsi dan memproduksinya pun harus berurutan dan sesuai dengan urutan halaman yang ada.Ini semua berbeda dengan media online yang menyajikan pola produksi dan konsumsi pesan yang tidak sama dengan media konvensional. Pengguna media online dibebaskan menentukan cara mengkonsumsi maupun memproduksi pesan yangada, sesuai dengan yang diharapkan penggunanya. Media website juga merupakan ruang publik yang ideal, yang memenuhi kriteria adanya kemudahan akses, kebebasan berekspresi, kesetaraan, sertakepastian hukum (Wood and Smith: 2005:41).

\section{Tujuan}

Tujuan dari penelitian ini adalah untuk mengetahui bagaimana pesan komunikasi yang disampaikan dalam usaha penggalangan dana melalui media website.
Dengan mengambil sampel dua jenis website sebagai Fundraiser, juga ingin melihat masing-masing persamaan dan perbedaan dari strategi komunikasi yang dilakukan.

\section{METODE}

Penelitian ini menggunakan pendekatan penelitian kualitatif dengan sifat penelitian deskriptif. Penelitian kualitatif adalah penelitian yang tidak mementingkan angka atau kuantifikasi fenomena. Dideskripsikan dengan kumpulan dan analisa data yang berupa kata-kata atau observasi langsung terhadap unit yang dianalisis. Pengumpulan data dilakukan dengan cara observasi terhadap dua sampel website yang terpilih yang selanjutnya dilakukan analisis isi. Analisis data dilakukan terhadap data berdasar logika induktif, yang selanjutnya akan diambil suatu kesimpulan.

\section{HASIL DAN PEMBAHASAN}

Pesan komunikasi yang dimaksud dalam proses komunikasi adalah sesuatu yang disampaikan pengirim kepada penerima. Dalam hal ini pesan disampaikan melalui media komunikasi khususnya website. Dalam penelitian inidilakukan analisis isi terhadap website tersebut. Pada dasarnya pesan komunikasi yang disampaikan merupakan praktek Public Relation dari perusahaan tersebut melalui website, karena Public Relation adalah manajemen komunikasi antara organisasi dengan publiknya (Grunig and Hunt, 1984, 98). Salah satu praktek public relations adalah mempertahankan citra baik lembaga / perusahaan di mata masyarakat/publik. Aktivitas komunikasi publik, pa-da dasarnyaberkaitan dengan tindakan sosialisasi dan pendidikan terhadap publik. Pada konteks ini, maka public relations harus bisa membentuk nilai-nilai,pemahaman, sikap-sikap, sampai perilaku dari publik agar sejalan dengan kebutuhan organisasi. Melalui pengemasan pesan-pesan komunikasi yang lebih banyak berisikan tentang apa dan siapa serta apa manfaat keberadaan organisasi. Opinipublik dan citra organisasi tentu saja merupakan 
faktor penting yangmenentukan sukses atau gagalnya aktivitas dan pelaksanaan program organisasi.

Selanjutnya dalam melakukan analisis, isi atau pesan komunikasi dibagi menjadi beberapa kategori, yaitu:

a. Akses penggalangan dana

b. Jenis penggunaan dana

c. Laporan penggunaan dana

d. Pesan pembentukan opini dan citra perusahaan.

Hasil dan pembahasan dari masingmasing website adalah sebagai berikut:

\section{Website Kitabisa.com}

Kitabisa.com didirikan pada Juli 2013 dan dalam websitenya nama perusahaan dan alamat serta kontak yang bisa dihubungi adalah sebagai berikut;

\begin{tabular}{l}
\hline PT. Kita Bisa Indonesia \\
Jl. Ciputat Raya no. 27D \\
Pondok Pinang, Kebayoran Lama \\
Jakarta Selatan 12310 \\
Telepon seputar donasi: \\
o852 8058 7434 / 021 750 9468 \\
Telepon seputar galang dana: \\
o828 1707 9823 \\
Email: support@kitabisa.com \\
Google Maps: ktbs.in/maps
\end{tabular}

Kitabisa.com juga memberikan fasilitas media sosial melalui Facebook, Twitter, dan Google Talk. Penggalangan dana Kitabisa bersifat crowdfunding (penggalang dana dari publik), dimana dana tersebut didonasikan oleh donatur kepada orang atau lembaga yang membutuhkan. Menu Utama jika kita membukawebsiteKitabisa.comadalahpilihan menu yang harus dipilih, apakah kita sebagai orang atau lembaga yang membutuhkan donasi dan akan berkampanye (galang dana) ataukah kita sebagai orang yang akan melalukan donasi (donasi). Terdapat dua pilihan bahasa yang dapat digunakan, yaitu bahasa Indonesia dan bahasa Inggris. Selain itu juga diinformasikan data terbaru tentang Jumlah kampanyeyang terdanai (1.047), Total donasi yang terkumpul (Rp. 11.491.541.374,-) dan Jumlah pengguna aktif (61.175), update data per awal April 2016.

\section{a. Akses penggalangan dana}

Kitabisa.com merupakan website yang memberikan sarana bagi warga masyarakat baik perorangan atau kelompok untuk mendapatkan dana melalui campaign atau kampanye yang dilakukan melalui website tersebut. Keberhasilan mendapatkan donasi sangat bergantung pada:

- Jaringan yang dimiliki inisiator kampanye (keluarga, teman, komunitas, dll)

- Kualitas konten/story telling

- Strategi promosi online

- Khusus kampanye yang penerima donasinya adalah individu, Kitabisa tidak menerima kampanye yang dilakukan oleh pemilik kampanye (orang yang ingin dibantu). Pemilik kampanye haruslah orang lain (selain keluarga inti) yang bersedia menjamin dan mengkampanyekan orang yang dibantu.

Berdasar kriteria di atas, maka pembuat kampanye adalah orang yang bisa membuat konten atau tulisan untuk dapat di promosikan agar mendapat dana, dengan strategi promosi yang baik kemungkinan mendapatkan dana akan lebih berhasil.Seorang pembuat kampanye yang melakukan verifikasi data akan mendapat kesempatan untuk dapat membuat maksimal tiga kampanye yang berbeda. Penerima donasi tidak perlu mengembalikan dana yang diterima. Selain melalui website, kampanye juga bisa dilakukan melalui media sosial facebook dan twitter.Untuk Facebook memiliki alamat www.facebook. com/kitabisacom/. Pengguna facebook yang memberikan like sebanyak 15.027 orang (per awal april 2016). Untuk twitter memiliki account @kitabisacom dengan jumlah pengikut sebanyak 12.800 orang (per awal april 2016). Berikut adalah salah satu contoh kampanye di bidang kesehatan, yang di kampanyekan atau di-share pemilik kampanye melalui media sosial twitter selain di website Kitabisa. 


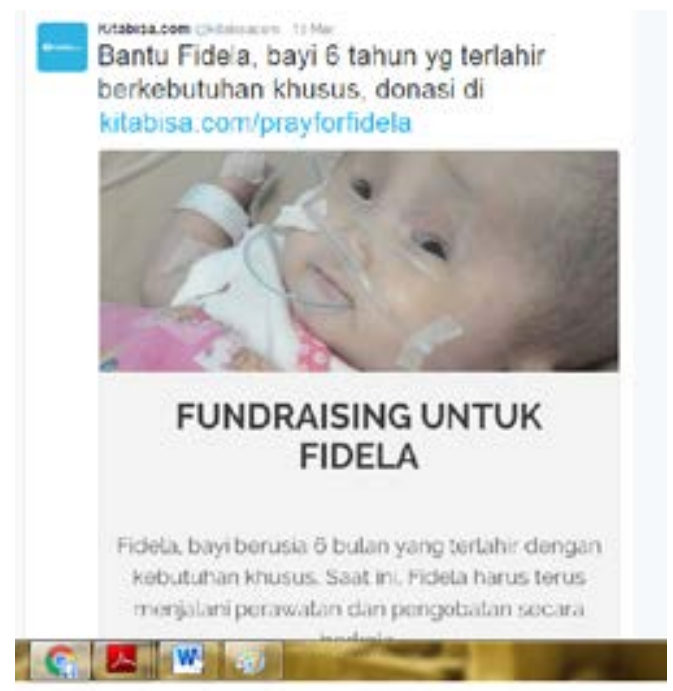

Gambar 1. Kampanye penggalangan dana melalui media twitter

Penggalangan dana dapat dilakukan juga oleh fundraiser. Fundraiser adalah status yang diperoleh oleh seorang donatur yang berhasil mengajak orang lain berdonasi. Fundraiser dapat mengajak orang lain untuk berdonasi dengan menyebarkan link fundraiser-nya melalui email, whatsapp, line, sms dan media kekinian lainnya:

Berikut adalah contoh informasi tentang data fundraiser.

\begin{tabular}{|l|}
\hline Paulus Ronald B. Nono \\
mengajak 14 orang berdonasi \\
Rp. 2.213.930 \\
Basa Nova Siregar \\
mengajak 1 orang berdonasi \\
Rp. 105.579 \\
\hline
\end{tabular}

\section{b. Jenis penggunaan dana}

Bidang yang dapat dipilih untuk penggunaan dana tersebut adalah:

- Kesehatan

Donasi bidang kesehatan bisa digunakan untuk biaya perawatan orang sakit, biaya operasi, dan lainnya.

- Pendidikan

Donasi bidang pendidikan bisa digunakan untuk membantu biaya pendidikan, dan lainnya

\section{- Infrastruktur}

Donasi bidang infrastruktur bisa digunakan untuk biaya pembangunan berbagai jenis infrastruktur.

- Emergency

Donasi bidang emergency bisa digunakan untuk membantu biaya segalakegiatanyangsifatnyamendesak untuk segera dilakukan, misal operasi suatu penyakit, membantu balita bergizi buruk, korban banjir, dan lainnya.

- Event

Donasi bidang event bisa digunakan untuk biaya pengadaan suatu kegiatan, misal kegiatan kemah budaya, pembuatan video tentang batik, dan lainnya.

\section{- Hadiah}

Donasi bidang hadiah bisa digunakan untuk memberikan sumbangan atau hadiah kepada yang membutuhkan, misal hadiah sepeda untuk sarana transportasi antar rumah singgah, hadiah untuk anak pedalaman.

- Hewan

Donasi bidang hewan bisa digunakan untuk hal-hal yang berhubungan dengan kelangsungan hidup hewan, misal kegiatan klinik hewan gratis, sterilisasi anjing / kucing terlantar, dan lainnya.

- Lingkungan

Donasi bidang lingkungan bisa digunakan untuk hal-hal yang berhubungan dengan kelestarian lingkungan, misal penanaman kembali pohon mangrove di pesisir pantai, pengelolaan sampah, dan lainnya.

- Olahraga

Donasibidangolahragabisadigunakan untuk hal-hal yang berhubungan dengan kegiatan keolahragaan, misal pengadaan bola dan perlengkapan sepak bola untuk pembinaan anakanak di suatu daerah, kegiatan duathlon (sepeda dan lari) untuk 
mendukung dana suatu yayasan, dan lainnya

- Produk dan Teknologi

Donasi bidang produk dan teknologi bisa digunakan untuk hal-hal yang berhubungan dengan produksi atau event yang berhubungan dengan teknologi, misal pembuatan aplikasi hilang-temu orang, membantu partisipasi lomba robot ke USA, dan lainnya.

- Sedekah

Donasibidangsedekah bisadigunakan untuk hal-hal yang berhubungan dengan pemberian bantuan kepada orang miskin (tidak mampu), misal pengadaan sekolah gratis untuk anak jalanan, membantu keluarga miskin, dan lainnya.

- Seni dan kreatif

Donasi bidang seni dan kreatif bisa digunakan untuk hal-hal yang berhubungan dengan kegiatandan kreatifitas seni, misal festifal budaya, pengiriman tim tari tradisional ke eropa, dan lainnya.

Bangun Kembali \#MasjidTolikara Papua

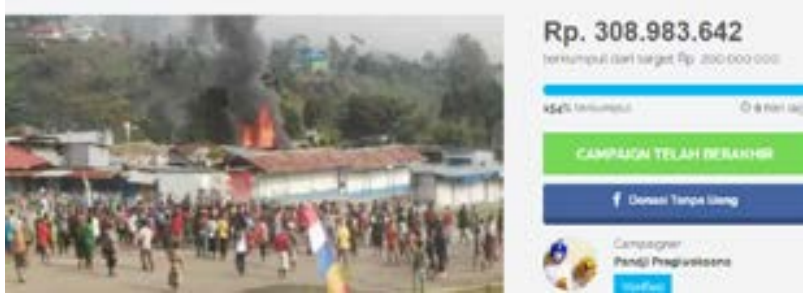

Gambar 2. Kampanye penggalangan dana bidang infrastruktur

\section{c. Laporan penggunaan dana}

Laporan penggunaan dana disini ada dua macam ;

1) Laporan dana yang berhasil dikumpulkan oleh pembuat kampanye

Pada saat kampanye diminta menyebutkan berapa target dana yang diharapkan, dan waktu yang diberikan adalah 48o hari. Setelah kampanye diluncurkan, maka akan terlihat laporan berapa persen donasi yang sudah terkumpul dan berapa hari waktu yang tersisa untuk masa kampanye.

Ada kalanya belum sampai habis waktu yang tersedia, dana yang dibutuhkan sudah terpenuhi, akan tetapi ada pula yang sampai habis waktu untuk kampanye tapi dananya belum terkumpul seperti yang diharapkan.

2) Laporan dana yang telah diberikan oleh donatur

Disini terdapat laporan kepada siapa saja donasi diberikan atau disalurkan dan berapa besarnya. Donasi yang diberikan minimal Rp. 50.000,- dan dapat dibayarkan melalui bank, yaitu BNI, BCA, BRI, Muamalat, dan Mandiri.
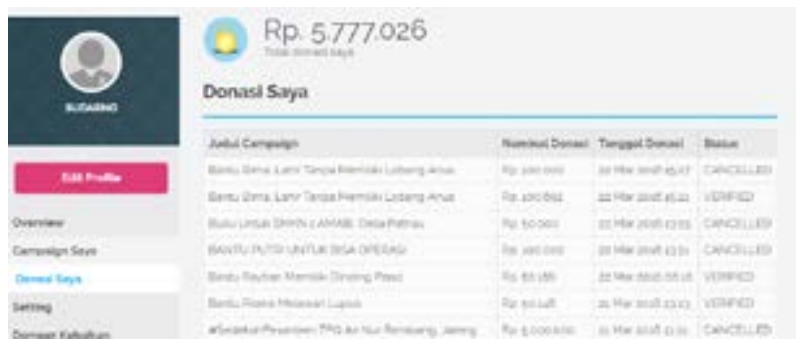

Gambar 3. Laporan penggunaan donasi pada salah satu account donatur

\section{d. Pesan pembentukan opini dan citra perusahaan}

Pembentukan opini dan citra perusahaan dilakukan dengan melaporkan atau meng-update perkembangan dari orang atau lembaga yang mendapat bantuan. Serta laporan bentuk kerjasama yang dilakukan dengan lembaga atau pihak lain. 


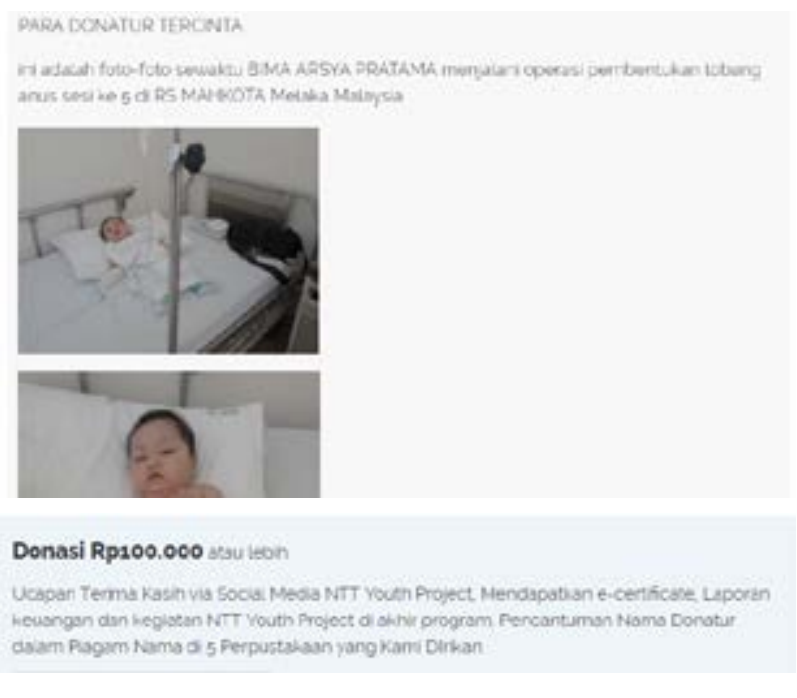

Gambar 4. Laporan perkembangan kesehatan penerima donasi dan laporan pemberian penghargaan kepada donatur dengan mendapat e-certificate.

\section{Kerjasama Kitabisa.com dengan Rumah Perubahan}

Rumah Perubahan didirikan oleh Profesor Rhenald Kasali pada tanggal o7 September 2007. Rumah Perubahandibangun dalam frame Social Entrepreneurship, sehingga aspek kewirausahaan yaitu kemandirian, inovasi, berorientasi pada hasil dan tindak nyata, serta mengedepankan proses dan etika yang selalu mewarnai perubahan yang digagas dan dilakukannya. Rumah Perubahan menjadi tempat bertemu dan digemblengnya para Agen Perubahan.

Mereka adalah calon-calon wirausaha, pelaku-pelaku perubahan, dan top executive dunia usaha, guru, pegawai negeri, aktivis lingkungan, agamawan, penegak keadilan, dan para pekerja sosial. Rumah Perubahan memberikan pelatihan dan melakukan kegiatan sosial dalam tiga bidang: pendidikan, kesejahteraan sosial, dan lingkungan hidup. Rumah Perubahan terbuka terhadap hal-hal baru dan kerjasamakerjasama untuk menggerakkan perubahan di masyarakat, manajemen dan dunia usaha, pendidikan, maupun ketatapemerintahan. RumahPerubahanmemberikanjasapelatihan dan konsultasi manajemen perubahan.

Selain itu Rumah Perubahan juga mengelola dana-dana sponsor CSR untuk perubahan. Tercatat Bank Mandiri, Bank Jabar Banten, Bank BNI, Yamaha, Astra International, Gramedia, ISS, dan sejumlah perusahaan lainnya mempercayakan sebagian program CSR-nya pada Rumah Perubahan. Untuk kemudahan komunikasi, Rumah Perubahan juga memperoleh jaringan satelit yang dibantu oleh program CSR dari Primacom.Rumah Perubahan juga memberikan pelatihan seputar perubahan, mulai dari Change Mangement, Changepreneuring, Pembentukan Change Agents, Management Therapy, Leadership Therapy, Corporate Culture Therapy, Entrepreneursip, Ethics for Entrepreneur, Service Excellence, Sales Therapy, Team Motivation \& Spirit, dan pelatihan serupa yang didesain secara khusus untuk setiap kepentingan.

\section{GandengTangan.com}

GandengTangan.com didirikan Maret 2015 dan dalam websitenya alamat serta kontak yang bisa dihubungi adalah sebagai berikut ;

Alamat:Jl. Cibulan 4 no.9
Kebayoran Baru, Jakarta Selatan
Info by email (tersedia form untuk
dikirim)

GandengTangan adalah wadah kolaborasi bagi pemilik usaha sosial yang membutuhkan modal dengan publik yang tulus ingin membantu dengan memberikan pinjaman. GandengTangan hadir untuk menjembatani keduanya agar dapat bergandengan tangan untuk menciptakan dampak baik bagi Indonesia. Lebih spesifiknya sifat penggalangan dana melalui GandengTangan adalah crowdlending (meminjam dana dari publik). Jadi donasi yang diterima oleh penerima donasi bersifat pinjaman dengan bunga o\%.GandengTangan juga bisa diakses melalui media sosial facebook dan twitter.Menu Utama jika kita membuka website GandengTangan.org adalah pilihan menu yang harus dipilih, apakah kita akan mengajukan usaha ataukah kita akan mendanai usaha. Terdapat motto di kiri atas website, 'help - empower - 
sustain' (membantu, memberdayakan, berkelanjutan). Selain itu juga ada menu jika ingin melihat video dari berbagai usaha yang mengajukan dana. Website facebook gandengtangan adalah www.facebook.com/ gandengtanganorg/ dengan jumlah like sebanyak 9.533 orang. Untuk twitter dengan account @gandeng_tangan dengan jumlah pengikut 581 orang, update data per awal april 2016.

\section{a. Akses penggalangan dana}

GandengTangan ditujukan untuk Wirausaha Sosial, yaitu wirausaha yang melakukan usaha untuk menyelesaikan permasalahan sosial, bukan hanya untuk keuntungan semata
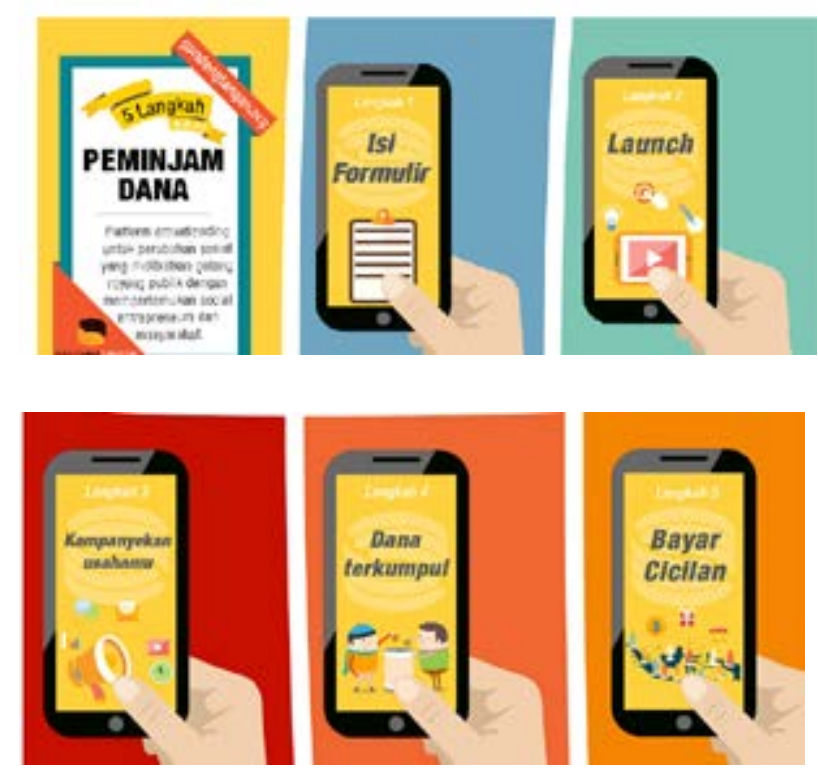

Gambar 5. Langkah-langkah penggalangan dana untuk mendapatkan donasi.

Apabila proposal diterima, peminjam bisa meluncurkan proyeknya dan melakukan kampanye penggalangan dana dengan durasi maksimal hingga 45 hari. GandengTangan akan mengambil potongan sebesar lima persen dari total pinjaman untuk keperluan administrasi. Disamping itu, para peminjam wajib menyetujui permohonan autodebit untuk pembayaran angsuran pinjaman. Proposal usaha harus melalui persetujuan pertanggungjawaban dari pihak-pihak tertentu seperti dari pemerintahan atau dari lembaga LSM. Kampanye yang dilakukan melalui website GandengTangan dapat berupa video, foto, narasi atau penjelasan tentang usaha yang membutuhkan donasi.

\section{b. Jenis penggunaan dana}

Jenis usaha yang dapat menggunakan dana melalui GandengTangan adalah usaha yang mempunyai dampak sosial, yaitu:

- Memberdayakan mereka yang kurang beruntung

- Melayani kebutuhan dari mereka yang tidak terlayani

- Mengurangi dampak negatif lingkungan dan sosial

Syarat lainnya adalah ;

- Usaha yang sudah beroperasi minimal 6 bulan

- Usaha yang memiliki tujuan bukan hanya mencari profit semata.

- Memiliki model bisnis dan alur pemasukan yang jelas

- Tidak dalam posisi kredit macet atau bangkrut

Aquatic Tropish Farm : Harapan Persediaan Ikan di Kutai, Kalimantan

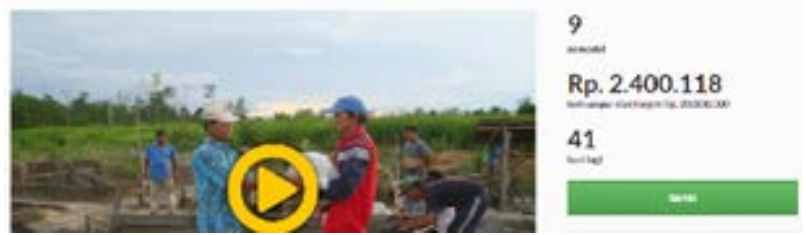

Gambar 6. Usaha yang mendapatkan dana pinjaman melalui GandengTangan.

\section{c. Laporan penggunaan dana}

Laporan penggunaan dana disini ada dua macam ;

1) Laporan dana yang berhasil dikumpulkan oleh pembuat kampanye

Peminjam yang merasa keberatan untuk membayar angsuran, bisa melakukan rekonstruksi pinjaman dengan menambah jangka waktu pinjaman dan menurunkan nilai angsuran. Dan apabila tidak 
sanggup membayar angsuran, jalan terakhir yang akan ditempuh adalah melikuidasi semua aset yang dibeli dengan pinjaman tersebut. Bentuk perjanjian pinjaman dan pembayaran angsuran antara peminjam dana dan GandengTangan tidak dapat diakses oleh pihak lain.Akan tetapi rincian donasi yang terkumpul dari target yang diharapkan dapat dipantau selama masa kampanye.

2) Laporan dana yang telah diberikan oleh donatur

Para donatur yang berminat memberikan donasi perlu mendaftar terlebih dahulu. Setelah itu, mereka harus melakukan sejumlah deposit dengan angka minimal Rp 50.000. Dana yang telah didonasikan akan dikembalikan secara otomatis ke deposit donatur untuk nantinya bisa disumbangkan keusahasosial lainatau dicairkan (withdraw). Terdapatrincian laporan donasi yang telah dikeluarkan dari masing-masing donatur. GandengTangan menambahkan sistem gratification, yang mana nantinya para donatur akan mendapatkan reward dari setiap donasi yang diberikan. Hal ini tentunya bukan menjadi alasan yang kuat untuk memberikan donasi, apalagi bagi para pengguna yang memiliki jiwa sosial yang kurang.
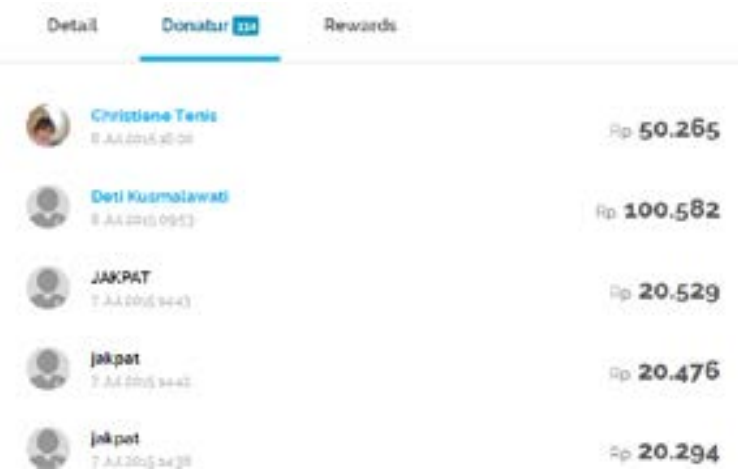

Gambar 7. Laporan dana yang telah diberikan oleh donatur kepada suatu proyek infrastruktur perpustakaan desa di NTT.

\section{d. Pesan pembentukan opini dan citra perusahaan}

Pembentukan opini dan citra perusahaan dilakukan dengan melaporkan atau meng update perkembangan dari usaha atau lembaga yang mendapat bantuan. Serta laporan bentuk kerjasama yang dilakukan dengan lembaga atau pihak lain. Kerjasama GandengTangan dengan lembaga lain diantaranya ;

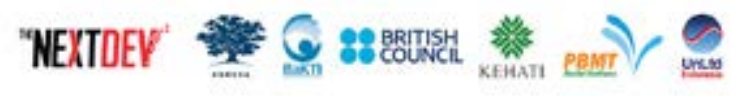

1. NextDev. NextDev adalah sebuah ajang kompetisi pembuatan aplikasi teknologi, baik website maupun mobile bagi anak muda Indonesia untukmembantupemecahanmasalah yang dihadapi kota-kota di Indonesia. Misi utama dari NextDev adalah membantu terwujudnya Smart City di perkotaan Indonesia dengan mengintegrasikan teknologi dalam segala aspek termasuk pemerintahan, penduduk, kesehatan, pendidikan dan transportasi. NextDev disponsori oleh Telkomsel. Sehubungan dengan kerjasamanya dengan GandengTangan, NextDev ingin memberdayakan UKM tanah air lewat aplikasi digital, mengedukasi UKM agar memanfaatkan teknologi untuk mempermudah proses bisnisnya berjalan lebih cepat dan efektif.

2. Ashoka Changemakers. Ashoka didirikan pada tahun 1980 yang merupakan perintis bidang kewirausahaan sosial global. Changemakers menghadapi kekuatan tantangan terbuka dengan pengetahuan inovasi sosial ditambah dengan jaringannya. Ashoka menghubungkan pengusaha sosial dan mitra untuk membuat perubahan yang berpotensi tinggi untuk mempercepat laju perubahan di sekitar isu-isu sosial yang penting. 
Prinsip-prinsip desain inti dari apa yang ditawarkan adalah untuk membingkai pemahaman dasar, pendekatan, hasil yang diinginkan, dan potensi untuk berkolaborasi, mengadakan jaringan yang kuat, baik online dan secara pribadi, serta memicu kerja untuk mempercepat laju perubahan di sekitar masalah sosial kritis. Ashoka Changemakers merupakan pelopor model bermitra dengan sektor publik dan organisasi multilateral untuk menjalankan kompetisi.

3. BaKTI. BaKTI berdiri tahun 2004 sebagai bagian dari unit pertukaran pengetahuan Support Office for Eastern Indonesia (SOfEI). SOfEI adalah proyek multi donor yang diadministrasi oleh Bank Dunia. Dengan maksud memperkuat kepemilikan lokal dan fungsi keberlanjutan, BaKTI resmi menjadi yayasan dibawah payung hukum Indonesia. Peresmian Yayasan BaKTI berlangsung tanggal 8 February 2010. BaKTI awalnya dibuat sebagai bank pengetahuan dan sumber informasi publik untuk pembangunan di Kawasan Timur Indonesia (KTI). Seperti diketahui bersama, KTI selalu menjadi target inisiatif pembangunan baik dari internasional, nasional dan lokal sendiri, akan tetapi banyak pengetahuan dan pembelajaran yang berharga tidak didayagunakan dengan baik sebagai bagian rencana pembangunan yang akan datang. BaKTI diciptakan untuk menyediakan platformdan alat tersebut untuk lembaga donor, pemerintah dan masyarakat untuk bisa mengakses informasi, menyimpannya, bertemu dan berdiskusi mengenai isuisu pembangunan serta prioritas apa yang harus diambil agar bisa lebih mempengaruhi pengambilan keputusan dan lebih mendukung aktivitas pembangunan yang berbasis pengetahuan. Produk dan layanan dari BaKTI adalah:

\section{a) BaKTINews}

Produk unggulan BaKTI dalam pemanfaatan media. Edisi pertama BaKTINews di awal tahun 2005. Sekarang, setiap bulan terbit dengan 32 halaman dan disajikan kepada kurang lebih 2,500 penerima per bulan dan 1,00o penerima dalam versi elektronik. Keterbacaan BaKTI sendiri bisa mencapai 10,000 orang setiap bulannya.

\section{b) Help Desk BaKTI}

Salah satu layanan yang penting disediakan oleh BaKTI adalah Information Help Desk. Sejak dibentuk sampai sekarang, BaKTI telah menjawab lebih dari 1500 permintaan informasi mengenai program pembangunan KTI dan memfasilitasi ratusan jaringan dan kolaborasi diantara organisasi dan individu baik itu dari pemerintah, mitrapembangunaninternasional, universitas, lembaga masyarakat, dan media. $25 \%$ queries berasal dari pemerintah dan selalu bertambah setiap tahun.

c) BaKTI sebagai sekretariat Forum KTI

BaKTI terus berperan sebagai sekretariat Forum KTI dengan mendukung pertemuanpertemuan regional dan provinsi untukmengembangkan kemitraan para pihak dalam menjawab tantangan pembangunan di Kawasan Timur Indonesia.

\section{d) Fasilitas BaKTI}

Fasilitas akses data publik dan perpustakaan beroperasi sejak pertengahan tahun 2005. Sekarang, lebih dari 6,500 orang mengunjungi fasilitas ini per tahun. Lebih dari 59,400 orang telah mengunjungi fasilitas BaKTI di Makassar sejak tahun 2005. Biasanya pengunjung BaKTI 
datang untuk mengakses bukubuku dan data pembangunan yang ada di perpustakaan untuk kepentingan riset dan membuat laporan sekaligus bertemu dengan yang lainnya atau mengakses fasilitas internet. Lebih dari 800 pertemuan, pelatihan dan event sudah dilaksanakan di BaKTI selama 9 tahun ini.

\section{e) Portal Pertukaran Pengeta- huan}

www.batukarinfo.com adalah portal pertukaran pengetahuan pertama di KTI dan diluncurkan tanggal o8 Februari 2008, banyakunique visitors mengakses Batukarinfo untuk menemukan informasi seputar pembangunan di KTI.

4. KEHATI. KEHATI (Keanekaragaman Hayati Indonesia) adalah yayasan yang berdiri sejak 12 Januari 1994 dimaksudkan untuk menghimpun dan mengelola sumberdaya yang selanjutnya disalurkan dalam bentuk dana hibah, fasilitasi, konsultasi dan berbagai fasilitas lain guna menunjang berbagai program pelestarian keanekaragaman hayati Indonesia dan pemanfaatannya secara adil dan berkelanjutan. Keberadaan Yayasan KEHATI tidak terlepas dari wujud pelaksanaan KTT Bumi di Rio de Janeiro tahun 1992 dan Deklarasi Tokyo tahun 1993 dimana pimpinan tiga negara yaitu Amerika Serikat, Jepang dan Indonesia sepakat bekerjasama untuk membantu program pelestarian keanekaragaman hayati secara berkelanjutan di Indonesia. Hibah yang diperoleh dari Amerika Serikat ini berbentuk dana cadangan abadi (endowment fund). Dana abadi ini diputar di pasar modal dalam bentuk saham dan obligasi. Hasil dari perputaran dana ini diperoleh imbalan yang dipakai untuk membiayai program bantuan hibah yang dilaksanakan oleh mitra KEHATI. Bantuan KEHATI dapat berbentuk dana hibah, tenaga ahli, konsultasi dan berbagai bentuk fasilitas bagi kegiatan LSM, KSM, lembaga penelitian, pendidikan \& pelatihan serta berbagai organisasi dan komponen masyarakat madani yang memiliki program dan kegiatan sejalan dengan program KEHATI, pelestarian dan pemanfaatan keanekaragaman hayati secara adil dan berkelanjutan.Dana hibah KEHATI diberikan kepada:

a) a. Mitra yang bekerja di tiga ekosistem prioritas: Pertanian, Kehutanan, Pesisir dan Pulaupulau Kecil. Program yang dilaksanakan merupakan program pelestarian dan pemanfaatan keanekaragaman hayati secara berkelanjutan. Jangka waktu program yang diajukan lebih dari 1 tahun.

b) b. Pendanaan hibah untuk program-program khusus MFP II, TFCA Sumatera dan TFCA Kalimantan, silahkan akses langsung ke: www.mfp.or.id, www.tfcasumatera.org, www. tfcakalimantan.or.id.

5. PBMT Social Ventures. PBMT Sosial Ventures bertujuan untuk memberantas kemiskinan di Indonesia dan bagian lain di Asia Tenggara dengan meningkatkan pembangunan masyarakat pedesaan melalui filantropi usaha. PBMT Sosial Ventures memanfaatkan pengalaman pengentasan kemiskinan dan jaringan di Indonesia yang telah dikembangkan selama lebih dari 10 tahun, menginspirasi dan menyarankan dermawan terhadap alokasi dana untuk kemiskinan serta mengurangi proyek berdampak sosial.PBMT Sosial Ventures bekerja untuk memperluas program di Asia Tenggara melalui kolaborasi dengan mitra lokal yang sesuai. PBMT Sosial 
Ventures menyediakan jasa konsultasi dan pendanaan serta dukungan manajemen kepada organisasi nonprofit yang tertarik untuk mengadopsi model BMT pemberantasan kemiskinan melalui filantropi usaha dan pembagian keuntungan dan kerugian sesuai keuangan mikro yang dapat dipertanggungjawabkan.

6. British Council. British Council didirikan untuk menciptakan pengetahuan dan pemahaman antara masyarakat Inggris dan dunia yang lebih luas, khususnya hubungan budaya.BC membantu membangun masyarakat yang lebih inklusif dan terbuka dan meningkatkan kesempatan anak-anak muda, mendorong mahasiswa internasional untuk datang dan belajar di Inggris, dan mahasiswa Inggris untuk mengalami kehidupan di luar negeri. Budaya dalam arti luas memainkan peran pentingdalam menghubungkan dan memahami satu sama lain.

BC menjalankan program dalam kemitraan dengan organisasi lokal dan internasional yang menyediakan keahlian dalam bidang-bidang seperti pemuda dan kewirausahaan sosial, kesempatan yang sama dan keragaman, migrasi, inklusi sosial dan keterlibatan dan kewarganegaraan aktif .

7. UnLtd. UnLtd dirancang untuk ; Pertama,calon pengusaha sosial atau masyarakat yang sudah mulai usaha sosial mereka selama minimal 6 bulan dan belum mendapatkan profit yang memadai.Sebuahpaketdukungandan pendanaan akan disesuaikan dengan proposal.Kedua, kewirausahaan yang dampak sosialnya sudah diidentifikasi , usaha berjalan pada skala kecil atau lokal, setidaknya selama enam bulan dan mungkin belum memiliki badan hukum. Ketiga, dirancang untuk perusahaan sosial yang sudah matang dalam bisnis dan membutuhkan bantuan untuk mengamankansumber daya untuk meningkatkan dampak dari bisnis sosial supaya tumbuh lebih kuat. Keempat, dirancang untuk perusahaan sosial yang ingin meningkatkan modal dari investor. Program ini adalah program intensif yang dirancang untuk membantu meningkatkan investasi eksternal (utang atau ekuitas). Ini akan membantu merancang rencana bisnis yang sehat, perbaikan presentasi bisnis, bagaimana menangani calon investor dan bagaimana membuat keputusan untuk bermitra dengan investor yang cocok.

Pembahasan dari kedua website tersebut untuk masing-masing kategori adalah ;

\section{a. Akses Penggalangan Dana}

Persamaan: Pencari dana menggunakan cara kampanye melalui website untuk dapat menggalang dana. Pembuatan kampanye membutuhkan ketrampilan dalam menyusun narasi, gambar/foto, pembuatan video dan lainnya, serta membuat link sebanyak mungkin melalui media yang lain (facebook, twitter, dll) agar kampanye dapat diakses banyak orang. Kampanye dilakukan dalam durasi waktu yang telah ditentukan.

Perbedaan:

\begin{tabular}{|l|l|l|}
\hline & Kitabisa.com & Gandengtangan.org \\
\hline $\begin{array}{l}\text { M a s a } \\
\text { kampanye }\end{array}$ & 480 hari & 45 hari \\
\hline $\begin{array}{l}\text { S e t e l a h } \\
\text { mendaftar }\end{array}$ & $\begin{array}{l}\text { Langsung bisa } \\
\text { berkampanye }\end{array}$ & $\begin{array}{l}\text { Ajukan proposal } \\
\text { dengan persetujuan } \\
\text { lembaga pemerintah } \\
\text { / LSM }\end{array}$ \\
\hline $\begin{array}{l}\text { Penggalang } \\
\text { dana }\end{array}$ & $\begin{array}{l}\text { Pembuat } \\
\text { kampanye } \\
\text { dan fundraiser } \\
\text { (donatur yang } \\
\text { juga mengajak } \\
\text { orang lain } \\
\text { berdonasi) }\end{array}$ & Pembuat kampanye \\
\hline
\end{tabular}

\section{b. Jenis Penggunaan Dana}

Persamaan: Penggunaan hasil penggalangan dana dapat digunakan untuk berbagai bidang kegiatan.

Perbedaan:

\begin{tabular}{|l|l|}
\hline Kitabisa.com & Gandengtangan.org \\
\hline
\end{tabular} 


\begin{tabular}{|l|l|l|}
\hline $\begin{array}{l}\text { Sifat } \\
\text { penggunaan } \\
\text { dana }\end{array}$ & $\begin{array}{l}\text { Bantuan atau } \\
\text { hibah }\end{array}$ & $\begin{array}{l}\text { Pinjaman dengan } \\
\text { bunga o\% }\end{array}$ \\
\hline $\begin{array}{l}\text { Penerima } \\
\text { dana }\end{array}$ & $\begin{array}{l}\text { Perorangan/ } \\
\text { kelompok/ } \\
\text { lembaga }\end{array}$ & $\begin{array}{l}\text { Bidang yang telah berdiri } \\
\text { minimal 6 bulan dan } \\
\text { berdampak sosial }\end{array}$ \\
\hline
\end{tabular}

\section{c. Laporan Penggunaan Dana}

Persamaan : Laporan dana untuk pembuat kampanye memperlihatkan berapa dana yang terkumpul untuk di donasikan dan waktu yang tersisa dalam masa penggalangan dana. Laporan dana untuk donatur memperlihatkan kepada siapa saja donasi diberikan dan berapa jumlahnya.

Perbedaan : Hampir tidak ada perbedaan dari laporan penggunaan dana.

\section{d. Pesan Pembentukan opini}

Persamaan: Memberikan laporan perkembangan dari penerima donasi dan bentuk kerjasama dengan pihak lain.

Perbedaan : Hampir tidak ada perbedaan dari penyampaian pesan pembentukan opini.

\section{SIMPULAN}

Penyedia website memberi fasilitas penggalangan dana. Penggalangan dana dilakukan oleh pihak pencari dana melalui kampanye di website yang berbentuk video, foto, tulisan, dan lainnya yang bisa diakses melalui website. Keberhasilan kampanye tergantung dari konten kampanye dan jaringan promosi kampanye. Penggalangan dana diperuntukkanuntukbidang kesehatan, pendidikan, infrastruktur, dan lainnya. Penggalangan dana yang bersifat meminjam diperuntukkan bagi usaha yang berdampak sosial.

Laporan penggalangan dana berisi target jumlah dana yang diharapkan oleh pencari dana dan rincian dana yang terkumpul dalam masa kampanye. Bagi donatur tersedia laporan rincian donasi yang telah diberikan. Pesan pembentukan opini dan citra perusahaan dilakukan dengan adanya pelaporan perkembangan kondisi penerima donasi, serta kerjasama pihak fundraiser (Kitabisa dan GandengTangan) dengan pihak lain dalam rangka penggalangan dana.

Perbedaan antara kedua fundraiser adalah, Kitabisa menggalang dana dengan sifat crowdfunding (penggalangan dana untuk didonasikan atau disumbangkan), masa kampanye 480 hari, dan tercantum jumlah orang yang berhasil diajak berdonasi (link) bagi para donatur. Sedangkan pada GandengTangan penggalangan dana bersifat crowdlending (pengumpulan dana untuk dipinjamkan), masa kampanye 45 hari, kampanye bisa dilakukan oleh pencari dana jika proposal diseujui, dan ada reward bagi para donatur. 


\section{DAFTAR PUSTAKA}

Jacques Defourny. 2010.Conceptions of Social Enterprise andSocial Entrepreneurship in Europe and theUnited States: Convergences andDivergences. Journal of Social Entrepreneurship. Vol. 1, No. 1, 32-53.

Muhsin, Kalida. 2004.Fundraising dalam Studi Pengembangan Lembaga Kemasyarakatan. Jurnal Aplikasi llmuilmu Agama, Vol. V, No. 2.148-16o.
Prihatini, Happy.2008. PESANKOMUNIKASI MELALUI WEBSITE DALAM PRAKTEK PUBLIC RELATIONS (Analisis Isi Website Pertamina, Chevron, dan Total

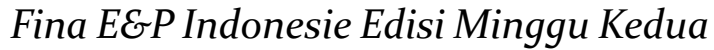
November 2007). Thesis. University of Muhammadiyah Malang.

Wood, Andrew F., Smith, Matthew J. 2005. Online Communication: Linking Technology, Identity and Culture. New Jersey. Lawrence Erlbaum Associates, Inc. 